\title{
Cloning of a novel insulin-regulated ghrelin transcript in prostate cancer
}

\author{
Inge Seim ${ }^{1,2}$, Amy A Lubik ${ }^{2,3}$, Melanie L Lehman ${ }^{2,3}$, Nadine Tomlinson ${ }^{3}$, \\ Eliza J Whiteside ${ }^{1,2}$, Adrian C Herington ${ }^{1,2}$, Colleen C Nelson ${ }^{2,3}$ and Lisa K Chopin ${ }^{1,2}$ \\ ${ }^{1}$ Ghrelin Research Group, Institute of Health and Biomedical Innovation (IHBI), Queensland University of \\ Technology, 60 Musk Avenue, Kelvin Grove, Brisbane, Queensland 4059, Australia \\ ${ }^{2}$ Australian Prostate Cancer Research Centre - Queensland, Princess Alexandra Hospital, Queensland University of \\ Technology, Woolloongabba, Queensland 4102, Australia \\ ${ }^{3}$ The Vancouver Prostate Centre, Vancouver, British Columbia, Canada V6H $3 Z 6$
}

Correspondence should be addressed to L K Chopin

Email

I.chopin@qut.edu.au

\begin{abstract}
Ghrelin is a multifunctional hormone, with roles in stimulating appetite and regulating energy balance, insulin secretion and glucose homoeostasis. The ghrelin gene locus (GHRL) is highly complex and gives rise to a range of novel transcripts derived from alternative first exons and internally spliced exons. The wild-type transcript encodes a 117 amino acid preprohormone that is processed to yield the 28 amino acid peptide ghrelin. Here, we identified insulin-responsive transcription corresponding to cryptic exons in intron 2 of the human ghrelin gene. A transcript, termed in2c-ghrelin (intron 2-cryptic), was cloned from the testis and the LNCaP prostate cancer cell line. This transcript may encode an 83 amino acid preproghrelin isoform that codes for ghrelin, but not obestatin. It is expressed in a limited number of normal tissues and in tumours of the prostate, testis, breast and ovary. Finally, we confirmed that in2c-ghrelin transcript expression, as well as the recently described in1-ghrelin transcript, is significantly upregulated by insulin in cultured prostate cancer cells. Metabolic syndrome and hyperinsulinaemia have been associated with prostate cancer risk and progression. This may be particularly significant after androgen deprivation therapy for prostate cancer, which induces hyperinsulinaemia, and this could contribute to castrate-resistant prostate cancer growth. We have previously demonstrated that ghrelin stimulates prostate cancer cell line proliferation in vitro. This study is the first description of insulin regulation of a ghrelin transcript in cancer and should provide further impetus for studies into the expression, regulation and function of ghrelin gene products.
\end{abstract}
Key Words
- ghrelin
- cryptic exon
- splicing
- testis
- prostate
- cancer
- insulin

Journal of Molecular Endocrinology (2013) 50, 179-191

\section{Introduction}

The 28 amino acid hormone ghrelin has emerged as a multifunctional peptide hormone with actions beyond its roles in GH secretion, appetite regulation and energy balance (Kojima et al. 1999, Wren et al. 2000, Nakazato et al. 2001, Lim et al. 2011). In addition to its role in normal physiology, ghrelin has been associated with a number of disease processes, including obesity (Scerif et al. 2011, Yi et al. 2011), type 2 diabetes mellitus and hyperinsulinaemia (Ukkola 2011), gastrointestinal disease (Jeffery et al. 2011), cardiovascular disease (Isgaard \& Granata 2011), reproductive disorders (Repaci et al. 2011), mental health (Steiger et al. 2011) and cancer (Chopin et al. 2011, Deboer 2011). Ghrelin may play a role in prostate cancer progression, and we have previously demonstrated that ghrelin mRNA and protein is expressed in prostate cancer cell lines and tissues and that ghrelin

Published by Bioscientifica Ltd. 
stimulates cell proliferation in prostate cancer cell lines (Jeffery et al. 2002, Yeh et al. 2005).

The ghrelin gene consists of four preproghrelin-coding exons (exons 1-4) that give rise to a 117 amino acid preproghrelin peptide (Kojima et al. 1999, Seim et al. $2011 b$ ). The first 23 amino acids are encoded by exon 1 and harbour a secretory signal peptide, while the remainder of exon 1 and part of exon 2 encode the 28 amino acid ghrelin peptide. Exon 3 encodes obestatin, a recently discovered 23 amino acid peptide hormone with a range of novel functions, including regulation of adipogenesis, insulin secretion and pancreatic homeostasis and cancer cell progression (Zhang et al. 2005, Seim et al. 2011b).

Following cleavage of the signal peptide, the 94 amino acid proghrelin peptide is post-translationally modified in the endoplasmic reticulum where an octanoyl fatty acid group (acyl group) is added to the third residue of ghrelin, a serine, by the recently discovered enzyme ghrelin $O$-acyl transferase (GOAT; Gutierrez et al. 2008, Yang et al. 2008). Although both ghrelin and desacyl ghrelin circulate in the blood, the levels of desacyl ghrelin are significantly higher (Date et al. 2000, Patterson et al. 2005, Holmes et al. 2009). This may be the result of the rapid conversion of ghrelin to desacyl ghrelin by esterases in the circulation (Beaumont et al. 2003, De Vriese et al. 2004, Satou et al. 2010, Eubanks et al. 2011). Alternatively, desacyl ghrelin may be produced from proghrelin in the absence of GOAT expression or when the fatty acid substrates for GOAT are unavailable (Takahashi et al. 2009). Only the acylated form of ghrelin is able to bind the cognate receptor, the GH secretagogue receptor type 1a (GHSR1a; Howard et al. 1996, Kojima et al. 1999), although alternative receptors for both acylated and desacyl ghrelin must also exist (Seim et al. 2011a). It has been demonstrated that GOAT and ghrelin play a crucial role in glucose balance, particularly in response to caloric restriction (Zhao et al. 2010); however, this finding has not been replicated in a number of mouse models (Yi et al. 2012). While the role of the ghrelin axis in insulin and glucose balance is currently unclear, ghrelin and GOAT may be useful therapeutic targets for treating insulin resistance (Kirchner et al. 2010, Romero et al. 2010, Lim et al. 2011). Insulin resistance is also common in prostate cancer patients after androgen deprivation therapy (Aggarwal et al. 2011).

It is now well established that the majority of genes generate alternative splice forms, many of which have novel functions (Nilsen \& Graveley 2010). This is particularly true for preprohormones, which frequently harbour a range of bioactive peptides. The ghrelin gene (GHRL) is no exception, and it is now realised that the ghrelin locus encodes multiple bioactive molecules derived by alternative transcriptional splicing, proteolytic cleavage of larger precursor peptides and by other post-translational modifications (Seim et al. 2009, 2011a).

Here, we report a novel preproghrelin splice variant termed in2c-ghrelin (intron 2-cryptic) that contains a novel exon sequence derived from intron 2 of the ghrelin gene and investigate its expression in cancer. We demonstrate that this novel transcript, as well as the recently described in1-ghrelin transcript (Kineman et al. 2007, Gahete et al. 2010, 2011), is upregulated in response to insulin treatment in the $22 \mathrm{Rv} 1$ and lymph node carcinoma of the prostate (LNCaP) prostate cancer cell lines and, therefore, they may have a role in prostate cancer progression, particularly in cases of hyperinsulinaemia.

\section{Materials and methods}

\section{Cell culture}

Cell lines were originally obtained from the American Type Culture Collection (ATCC; Rockville, MD, USA). The PC3 (ATCC CRL-1435), DU145 (ATCC HTB-81), LNCaP (ATCC CRL-1740) and 22Rv1 (ATCC CRL-2505) prostate cancer cell lines were maintained in RPMI 1640 medium (Invitrogen) with 10\% New Zealand Cosmic Calf Serum (FCS, HyClone, South Logan, UT, USA) supplemented with $100 \mathrm{U} / \mathrm{ml}$ penicillin $\mathrm{G}$ and $100 \mu \mathrm{g} / \mathrm{ml}$ streptomycin (Invitrogen). All cell lines were passaged at 2- to 3-day intervals at $70 \%$ confluency using $0.25 \%$ trypsin/EDTA $(380 \mathrm{mg} / \mathrm{ml}$ or $0.913 \mathrm{mM}$ EDTA and $2500 \mathrm{mg} / \mathrm{ml}$ or $0.105 \mathrm{mM}$ trypsin; Invitrogen). Cell morphology and viability was monitored by microscopic observation and regular testing was performed by PCR (Universal Mycoplasma Detection Kit, ATCC) to ensure that cells were not contaminated with Mycoplasma.

\section{Microarray profiling of insulin-treated LNCaP prostate cancer cell line}

To identify RNAs expressed in the prostate that could be developed as disease-specific targets for prostate cancer treatment, we employed a custom-designed microarray from the Vancouver Prostate Centre (VPC). The microarray, an Agilent custom $2 \times 105 \mathrm{~K}$ array (Agilent Technologies, Wilmington, DE, USA), combines the probes from the Agilent $44 \mathrm{~K}$ (v1) human gene expression set with probes targeting alternative protein isoforms and

Published by Bioscientifica Ltd. 
non-coding RNAs. All probes on the microarray were classified based on their relationship to the RNAs in the NCBI RefSeq database (http://www.ncbi.nlm.nih.gov/ RefSeq; December 2010).

LNCaP prostate cancer cells were seeded on $10 \mathrm{~cm}$ tissue culture flasks (Nunc International, Penfield, NY, USA) in phenol red-free RPMI 1640 medium with 5\% FCS (Invitrogen) and left overnight to attach. The following day, serum was replaced with $5 \%$ charcoalstripped serum (Invitrogen) for $48 \mathrm{~h}$, followed by a $24-\mathrm{h}$ incubation in serum-free medium and treatment with $10 \mathrm{nM}$ insulin (Sigma-Aldrich) or an equal volume of vehicle $(70 \%$ ethanol) for $10 \mathrm{~h}$. All treatments were performed in triplicate. Total RNA was isolated using TRIzol (Invitrogen); one-colour gene expression analysis was performed following Agilent labelling (Quick Amp Labeling Kit), hybridisation and scanning (Agilent Feature Extraction version 10.5.1) protocols using the custom Agilent $2 \times 105 \mathrm{~K}$ microarray. Data were normalised using the quantile normalisation method in Linear Models for Microarray Data (LIMMA), an open-source R-based Software package for the analysis of gene expression data (Smyth 2005). Differential gene expression was determined using LIMMA linear models with an false discovery rate (FDR)-adjusted $P$ value $\leq 0.05$ and fold change $\geq 1.5$.

\section{In silico and RT-PCR verification of putative ghrelin exons identified by microarray analysis}

To investigate whether novel exons identified by microarray analysis correspond to splice variants of the preproghrelin gene (GHRL), and to determine the open reading frame of any resulting full-length transcript, we performed BLAST queries (Johnson et al. 2008), UCSC
Genome Browser multigenome alignments (specifically, the 17-way conservation track; Fujita et al. 2011) and RT-PCR with primers spanning the putative exons (in2c-ghrelin-ORF-F/R, Table 1). Briefly, for RT-PCR analyses, $2 \mu \mathrm{g}$ total RNA from human testis and pancreas (FirstChoice, Ambion, Austin, TX, USA), and from the LNCaP prostate cancer cell line, were subjected to DNaseI digestion (amplification grade, Invitrogen) and cDNA synthesis with SuperScript III and oligo(dT) $)_{18}$ primers (Invitrogen) according to the manufacturer's instructions. RT-PCR was performed in a total reaction volume of $50 \mu \mathrm{l}$ containing $1 \times \mathrm{PCR}$ buffer, $0.2 \mathrm{mM}$ deoxynucleotide triphosphates, $1.5 \mathrm{mM} \mathrm{MgCl}_{2}, 0.2 \mu \mathrm{M}$ primers (in2c-ghrelinORF-F/R, Table 1), $1 \mu \mathrm{l}$ cDNA and 1 unit of Platinum Taq DNA Polymerase (Invitrogen) on a PTC-200 thermal cycler (MJ Research, Watertown, MA, USA) according to the manufacturer's instructions. Negative, no-template controls were performed.

\section{Quantitative real-time RT-PCR of cultured cells and tissues}

Unless otherwise noted, total RNA was harvested from cultured cells using QIAshredder and RNEasy Plus Mini Kits (Qiagen), according to the manufacturer's instructions, and stored frozen at $-80^{\circ} \mathrm{C}$. RNA concentration and purity were measured using a NanoDrop ND-1000 spectrophotometer (Thermo Fisher Scientific, Scoresby, Victoria, Australia) to ensure adequate RNA quality. Contaminating genomic DNA was removed by DNaseI digestion (amplification grade, Invitrogen), and $2 \mu \mathrm{g}$ total RNA were reverse transcribed with oligo $(\mathrm{dT})_{18}$ primers using SuperScript III (Invitrogen). The prostate cancer cell lines described earlier, as well as RNA previously isolated from cell lines derived from normal lung (Beas-2B, ATCC CRL-9609),

Table 1 Designations and sequences of RT-PCR primers. Annealing temperatures $\left(T_{\mathrm{a}}\right)$ of oligonucleotide primers employed in RT-PCR and the expected product sizes are shown

\begin{tabular}{|c|c|c|c|}
\hline Primer name & Primer sequence & $\boldsymbol{T}_{\mathbf{a}}\left({ }^{\circ} \mathrm{C}\right)$ & $\begin{array}{l}\text { Expected } \\
\text { size }(b p)\end{array}$ \\
\hline In2c-ghrelin-ORF & $\begin{array}{l}\text { F: CTTCCTGAGCCCTGAACACC } \\
\text { R: TCAGCCTTAGCCTCTAATGGGA }\end{array}$ & 64 & - \\
\hline In2c-real & $\begin{array}{l}\text { F: AGAGGCATGAGAGTGCAAGTTC } \\
\text { R: GATGTCCTGAAGAAACTTCCCC }\end{array}$ & 64 & 131 \\
\hline In1-real & $\begin{array}{l}\text { F: TCTGGGCTTCAGTCTTCTCC } \\
\text { R: GTTCATCCTCTGCCCCTTCT }\end{array}$ & 60 & 215 \\
\hline wt-real & $\begin{array}{l}\text { F: TCAGGGGTTCAGTACCAGCA } \\
\text { R: CAAGCGAAAAGCCAGATGAC }\end{array}$ & 60 & 158 \\
\hline RPL32 & $\begin{array}{l}\text { F: CCCCTTGTGAAGCCCAAGA } \\
\text { R: GACTGGTGCCGGATGAACTT }\end{array}$ & 60 & 59 \\
\hline $18 \mathrm{~S}$ & $\begin{array}{l}\text { F: TTCGGAACTGAGGCCATGAT } \\
\text { R: CGAACCTCCGACTTTCGTTCT }\end{array}$ & 60 & 151 \\
\hline
\end{tabular}

http://jme.endocrinology-journals.org DOI: 10.1530/JME-12-0150
(C) 2013 Society for Endocrinology Printed in Great Britain
Published by Bioscientifica Ltd. 
non-small-cell lung cancer (A549, ATCC CCL-185 and NCI-H1299, ATCC CRL-5803), normal ovary (hOSE17.1), ovarian cancer (SKOV-3, ATCC HTB77) and breast cancer (MDA-MB231, ATCC HTB-26), were examined. Quantitative real-time RT-PCR was performed using primers in 2c-real-F/R (Table 1) with $2 \times$ SYBR green master mix (Applied Biosystems) on a PRISM 7000 Sequence Detection System (Applied Biosystems). Data were analysed using the comparative $2^{-\Delta \Delta C t}$ method (Livak \& Schmittgen 2001). Expression in different samples is shown as fold change (relative values) compared with a calibrator sample (value denoted as 1) after normalisation to the $18 \mathrm{~S}$ ribosomal RNA housekeeping gene. Primers are shown in Table 1.

Normal human tissue (HMRT102) and cancer (CSRT103) cDNA panels were purchased from OriGene (Rockville, MD, USA). HMRT102 consists of 48 normal tissues (adrenal gland, bone marrow, brain, breast, cervix, colon, duodenum, epididymis, fat, heart, small intestine, intracranial artery, kidney, liver, lung, lymph node, peripheral blood leucocytes, muscle, nasal mucosa, oesophagus, optic nerve, ovary, oviduct, pancreas, penis, pericardium, pituitary, placenta, prostate, rectum, retina, seminal vesicles, skin, spinal cord, spleen, stomach, testis, thymus, thyroid, tongue, tonsil, trachea, urethra, urinary bladder, uterus, uvula, vagina and vena cava), while CSRT103 consists of two to six normal and $\sim 20$ tumour samples from a range of tissues. In2c-ghrelin was interrogated as detailed earlier using the AB PRISM 7000 Sequence Detection System in a total reaction volume of $20 \mu \mathrm{l}$ using $2 \times$ SYBR green master mix (Applied Biosystems) on separate, identical array plates, which were loaded with equal amounts of cDNA per well.

\section{Quantitative real-time RT-PCR analysis of the effect of insulin on in2c-ghrelin and in1-ghrelin expression in cultured prostate cancer cells}

In order to verify the microarray data, which indicated that the novel in2c-ghrelin transcript is upregulated by insulin, we performed qRT-PCR on RNA extracted from the LNCaP and 22Rv1 prostate cancer cell lines. The LNCaP and 22Rv1 prostate cancer cell lines were cultured in six-well plates in phenol red-free RPMI 1640 (Invitrogen), as outlined earlier, except that cells were treated with $10 \mathrm{nM}$ insulin (Sigma-Aldrich) for $48 \mathrm{~h}$. Insulin was refreshed after $24 \mathrm{~h}$. RNA extractions and qRT-PCR were performed as outlined earlier. In1-ghrelin (in1-real-F/R, Table 1) and wild-type ghrelin (wt-real-F/R, Table 1) were detected using primer sequences published by Gahete et al. (2010, 2011). All treatments were performed in triplicate.
Data were analysed using the comparative $2^{-\Delta \Delta C t}$ method (Livak \& Schmittgen 2001). Ribosomal protein, L32 (RPL32F/R, Table 1), which is particularly suitable for cultured prostate cancer cells (Lubik et al. 2011), was employed as a housekeeping gene for qRT-PCRs.

\section{RT-PCR product purification and sequencing}

All RT-PCR products were, unless noted, purified using a MinElute (Qiagen) PCR Purification Kit, cloned into pGEM-T Easy (Promega), transformed into One Shot MAX Efficiency $D H 5 \alpha$-T1R chemically competent cells (Invitrogen) and sequenced at the Australian Genome Research Facility (AGRF, Brisbane, Queensland, Australia) using BigDye III (Applied Biosystems).

\section{Statistical analyses}

Data are expressed as mean \pm s.D. Statistical significance was determined using Student's $t$-test using GraphPad Prism (La Jolla, CA, USA) or Microsoft Excel Software with a $P$ value $<0.05$ considered to be statistically significant.

\section{Results}

Identification and cloning of novel, cryptic exons of the ghrelin gene (GHRL)

Using human exon-junction microarray probes, novel exons (named I and II) located in intron 2 of GHRL were found to be upregulated 3.9-fold by treatment with $10 \mathrm{nM}$ insulin in the LNCaP prostate cancer cell line (Fig. 1). These exons match four GenBank entries (EF139854-57) that partially overlap the ghrelin coding exons and contain novel exon sequence in intron 2 (Fig. 2). Interestingly, the GenBank entries are previously unpublished RT-PCR validations of testis-specific exons, which were identified in a large-scale study by Clark et al. (2007). Their study employed exon arrays to locate tissuespecific exons in 16 normal tissues, but focused on novel, brain-enriched exons in the published manuscript (Clark et al. 2007). To verify whether the novel exons correspond to splice variants of the ghrelin gene and to determine the open reading frame of these transcripts, RT-PCRs were performed (using cDNA reverse transcribed with oligo(dT) 18 primers) using RNA from the LNCaP prostate cancer cell line, human testis and pancreas (with a forward primer in exon 1 of ghrelin and a reverse primer in the novel exon II, which is common to all of the testis-derived GenBank entries). A single, major amplicon was obtained

Published by Bioscientifica Ltd. 


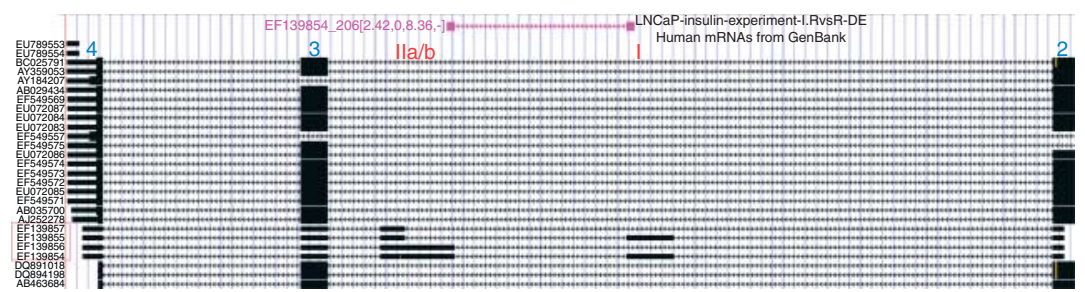

\section{Figure 1}

Image depicting mRNA transcript architecture in the GHRL locus was obtained through the UCSC Genome Browser. Microarray analysis detected a 3.9-fold increase in the expression of novel exons (indicated in pink) in intron 2 of the ghrelin gene (GHRL). Wild-type preproghrelin-coding

in the testis and LNCaP cell line, representing exons 1 , 2 and II of GHRL (Fig. 1; Supplementary Figure 1, see section on supplementary data given at the end of this article; GenBank: JN243773). We have termed the identified full-length splice variant in2c-ghrelin (intron 2 cryptic-ghrelin). The exons for in 2c-ghrelin have canonical GT/AG splice junctions, with the exception of the intron flanking a $5^{\prime}$ truncated exon II, exon IIb, which harbours a rare GT/AC junction (Burset et al. 2000; Fig. 2). The cryptic exons in the human gene are not conserved in the mouse or rat, which would, therefore, be unlikely to express the in2cghrelin isoform (data not shown). These analyses demonstrate that the human GHRL gene contains additional exons within intron 2 that are bona fide internal exons of preproghrelin splice variants that harbour exons 1-4.

The novel in2c-ghrelin isoform includes cryptic exons that lead to a frameshift in the translation of preproghrelin. The 83 amino acid in2c-ghrelin isoform harbours the coding region for the 28 amino acid mature ghrelin exons 2-4 are indicated in blue font, while the cryptic exons are indicated in red font. GenBank entries corresponding to the novel cryptic exons are indicated by a red box.

peptide (Fig. 3). While the C-terminal (C-ghrelin) region of wild-type ghrelin encodes a 66 amino acid peptide, the open reading frame of in2c-ghrelin encodes the first 24 amino acids of the C-ghrelin sequence and eight unique C-terminal residues, before the introduction of a stop codon. As a result of the frameshift, it lacks the coding sequence for obestatin (Fig. 3). The 3 ' untranslated region of the mRNA is otherwise identical to wild-type ghrelin and has the same polyadenylation signal.

\section{Quantification of in2c-ghrelin in normal tissues}

To selectively amplify the in2c-variant and to avoid co-amplification of ghrelin pre-mRNA or genomic DNA, we designed a reverse qRT-PCR primer that spans the exon II-exon 3 junction (Supplementary Figure 2, see section on supplementary data given at the end of this article). Quantitative real-time RT-PCR analyses of 48 tissues show that in2c-ghrelin mRNA, in contrast to

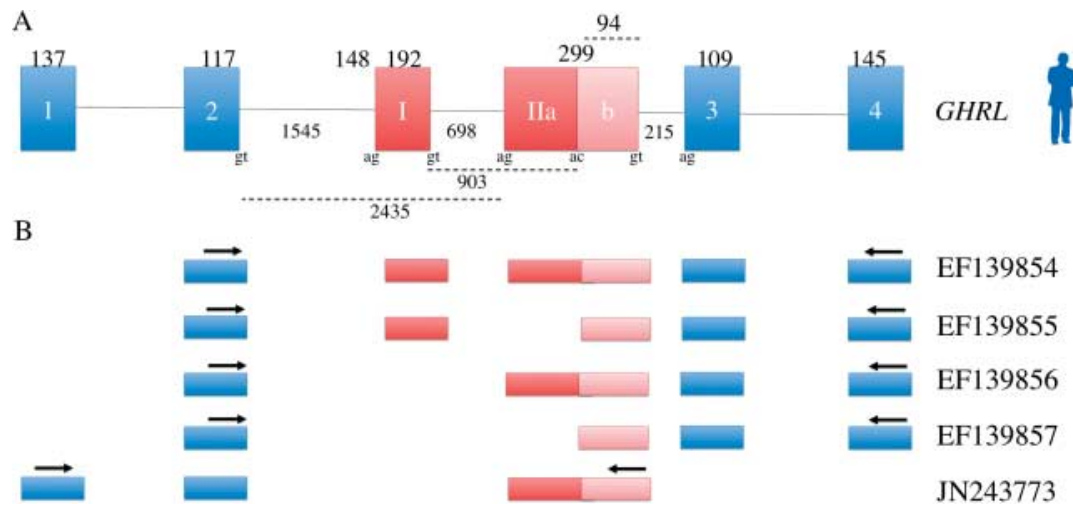

Figure 2

(A) Overview of the ghrelin locus showing the ghrelin gene, GHRL, with wild-type preproghrelin-coding exons in blue and the cryptic exons in intron 2 as red boxes (IIa, and the $5^{\prime}$ truncated exon Ilb). Exons are represented as boxes and introns as horizontal lines. (B) Mapping of the novel cryptic exon ghrelin transcripts. The exon structure of amplicons is derived from the human testis and LNCaP cells. Exons are represented as boxes, and RT-PCR primers are indicated as arrows above exons. http://jme.endocrinology-journals.org DOI: 10.1530/JME-12-0150
(๑) 2013 Society for Endocrinology Printed in Great Britain
Published by Bioscientifica Ltd 


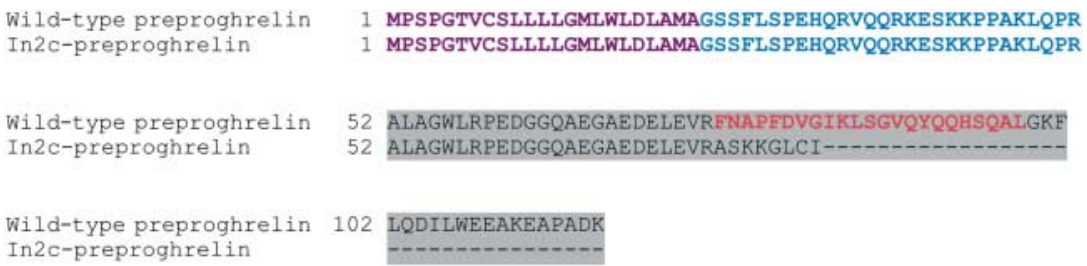

Figure 3

Multiple sequence alignment of wild-type preproghrelin and putative in2c-preproghrelin. Secretion signal peptides are shown in purple, ghrelin in blue, obestatin in red and C-ghrelin is highlighted in grey.

the wild-type ghrelin transcript (Gnanapavan et al. 2002, Ueberberg et al. 2009), is expressed in a small number of tissues, including the stomach, lymph node, peripheral blood leucocytes, testis, epididymis, skin and adrenal gland (Fig. 4).

\section{Quantification of in2c-ghrelin in cell lines}

Next, we examined the expression of in2c-ghrelin in cultured cells using qRT-PCR. In2c-ghrelin was highly expressed in the PC3, LNCaP and 22Rv1 prostate cancer cell lines, while the DU145 prostate cancer cell line did not express this transcript (Fig. 5). In2c-ghrelin expression was low in the lung, ovarian and breast cell lines examined. Interestingly, in2c-ghrelin is expressed in the SKOV-3 ovarian cancer cell line but not in the hOSE1.7 normal ovarian cell line (Fig. 5).

\section{In2c-ghrelin expression in normal vs tumour samples}

To further explore the role of in $2 c$-ghrelin in cancer, we analysed the expression of the variant using commercial cDNA arrays from OriGene. In the testis cDNA tissue panel, in2c-ghrelin was expressed in normal testicular tissue but is absent or present at low levels in testicular tumour samples (Fig. 6A). Conversely, prostate tumours exhibited high levels of in2c-ghrelin compared with normal prostate tissue (with 9/19 expressing higher levels than normal tissue and 14/19 prostate tumours expressing the variant; Fig. 6B). Finally, normal breast (Fig. 6C) and ovary (Fig. 6D) samples did not express in2c-ghrelin, while the transcript was expressed in 13/20 breast tumours and 7/21 ovarian tumours examined. Together, these results demonstrate that in2c-ghrelin is expressed at high levels in prostate cancer cell lines and prostate tumour tissue. It is expressed in all normal testis samples examined, while its expression is low or absent in testicular tumours, and it is expressed in breast and ovarian tumour, but not normal tissue.
In2c-ghrelin expression is regulated by insulin in prostate cancer cells

The microarray experiment revealed that in2c-ghrelin was regulated by insulin in LNCaP prostate cancer cells; therefore, we confirmed that this transcript is insulin regulated using quantitative RT-PCR of the LNCaP and 22Rv1 prostate cancer cell lines. As shown in Fig. 7A, treatment with $10 \mathrm{nM}$ insulin significantly increased the expression of in2c-ghrelin in the LNCaP (1.3-fold, $P<0.05)$ and 22Rv1 (4.4-fold, $P<0.05)$ prostate cancer cell lines. Interestingly, insulin also significantly upregulated the expression of a recently reported intron 1-retained transcript, in1-ghrelin (Kineman et al. 2007, Gahete et al. 2010, 2011). A 2.2-fold increase in expression was observed in LNCaP cells and a 2.8-fold increase in 22Rv1 cells (Fig. 7B).

\section{Discussion}

We have demonstrated a new ghrelin isoform that is regulated by insulin treatment in prostate cancer cell lines. Cryptic exon sequence in the in2c-ghrelin variant leads to a frameshift in the translation of preproghrelin

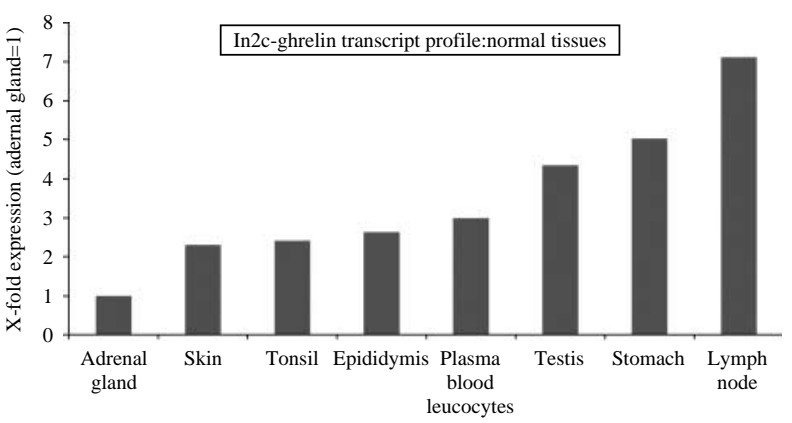

Figure 4

Relative expression of in2c-ghrelin in human tissues by quantitative realtime RT-PCR. Data were normalised to $\beta$-actin and are represented as fold changes relative to the expression in the adrenal gland (1.0).

Published by Bioscientifica Ltd. 


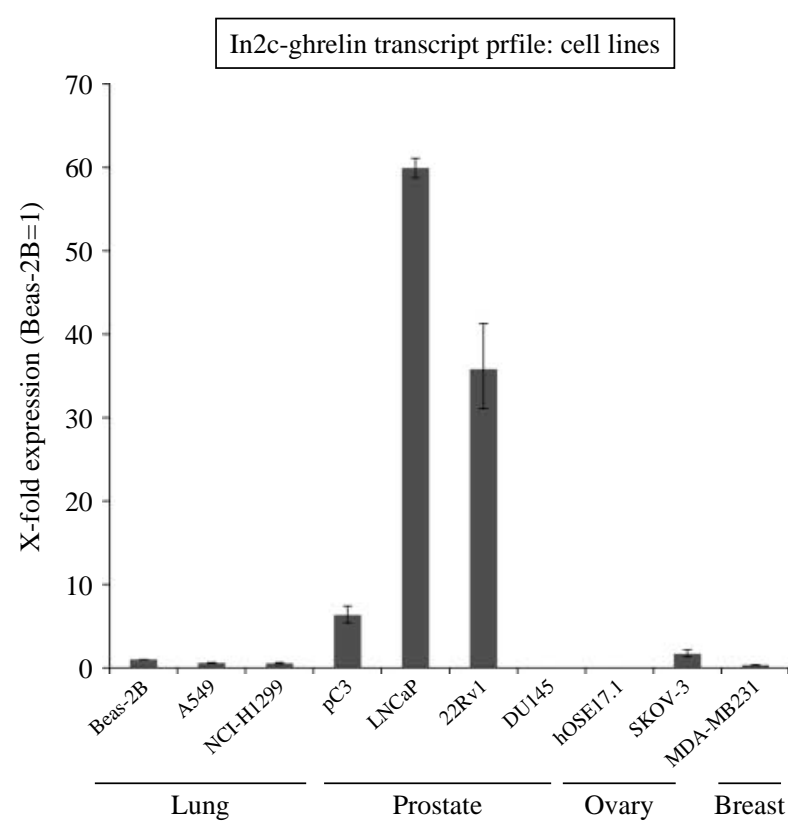

Figure 5

Relative expression of in2c-ghrelin in human cell lines using quantitative real-time RT-PCR. Data are represented as mean and s.E.M. from two technical replicates of two independent replicate experiments $(n=2)$. The housekeeping gene, 185 ribosomal RNA, was used as a reference for normalisation. Data are represented as fold changes relative to expression of transcripts in the Beas-2B normal lung cell line (set at 1 ).

and leads to an open reading frame that would encode an 83 amino acid preproghrelin peptide, which is considerably shorter than the 117 amino acid wild-type form. This isoform contains the 28 amino acid ghrelin but lacks the coding sequence for obestatin.

This study provides further evidence that microarrays, and in particular exon arrays where probes are designed to detect individual exons, are excellent tools to discover novel alternative transcripts (Clark et al. 2007, French et al. 2007, Skotheim \& Nees 2007, Rahman et al. 2010, Menghi et al. 2011). The exon-junction probe in our custom array was designed to target GenBank sequences deposited by Affymetrix as a result of RT-PCR validation of testisenriched exon array data (Clark et al. 2007). Alternative splicing results in cell- or tissue-specific expression of exons and is frequently observed in cancer (Skotheim \& Nees 2007, He et al. 2009, Nilsen \& Graveley 2010).

We have previously demonstrated that ghrelin mRNA and protein is expressed in prostate cancer cell lines, using RT-PCR and western blotting (Jeffery et al. 2002, Yeh et al. 2005). Expression of the ghrelin peptide has been demonstrated in prostate cancer cell lines using western analysis and in clinical specimens of prostate cancer using immunohistochemistry. Using these methods, it is not possible to discriminate between the expression of wildtype ghrelin and the in2c-ghrelin peptide isoforms at the peptide level. The in2c-ghrelin mRNA isoform appears to be particularly highly expressed in prostate cancer cell lines and tissues but is expressed at low levels or is absent in normal prostate tissue, which may indicate that the variant could be a useful diagnostic or prognostic marker for this cancer. A recent in vitro binding study using a fluorescein-labelled ghrelin-derived probe (consisting of the first 18 amino acids of ghrelin) has demonstrated that ghrelin may have potential as a diagnostic or prognostic marker for prostate cancer (Lu et al. 2012). Ghrelin binding was significantly higher in clinical samples of prostate cancer compared with normal tissue and samples of benign prostate hyperplasia in a study with 13 patients undergoing radical prostatectomy (Lu et al. 2012). If this probe is effective in vivo, it could be combined with positron emission tomography scanning and be useful for discriminating between benign disease and cancer and possibly for detecting micrometastases (Lu et al. 2012).

Treatment with acylated ghrelin stimulates cell proliferation through the ERK1/2 pathway in the PC3 and LNCaP prostate cancer cell lines (Jeffery et al. 2002, Yeh et al. 2005). Ghrelin may stimulate cell proliferation by acting through the GHSR1a, which is expressed in prostate cancer cell lines (Jeffery et al. 2002, Yeh et al. 2005), although it is also possible that ghrelin may act through the unidentified, widely hypothesised alternative ghrelin receptor (Chopin et al. 2012). We have demonstrated that GOAT is expressed in prostate cancer cell lines (I Seim, P Jeffery, L Amorim, A Herington \& L Chopin 2012, unpublished observation), indicating that ghrelin may be acylated in these cells. The role of ghrelin in prostate cancer growth remains uncertain, however. A similar increase in cell proliferation in response to ghrelin treatment was seen in the PC3 cell line in another study using lower concentrations of ghrelin, while supraphysiological levels $(1000 \mathrm{nM})$ inhibited proliferation in this study (Cassoni et al. 2004). Recently, a third laboratory demonstrated that ghrelin decreases proliferation and promotes apoptosis of PC3 cells (Diaz-Lezama et al. 2010). In this study, however, the investigators measured tritiated thymidine incorporation (DNA synthesis) in the last $6 \mathrm{~h}$ of a 72-h ghrelin treatment, and it is unlikely that ghrelin would have been intact at this point of the experiment. Ghrelin is unstable in culture, with a short half-life, with the octanoyl group (acylation) being rapidly lost and the peptide rapidly cleaved (De Vriese et al. 2004, Hosoda et al. 2004). Contrasting observations have also

Published by Bioscientifica Ltd. 

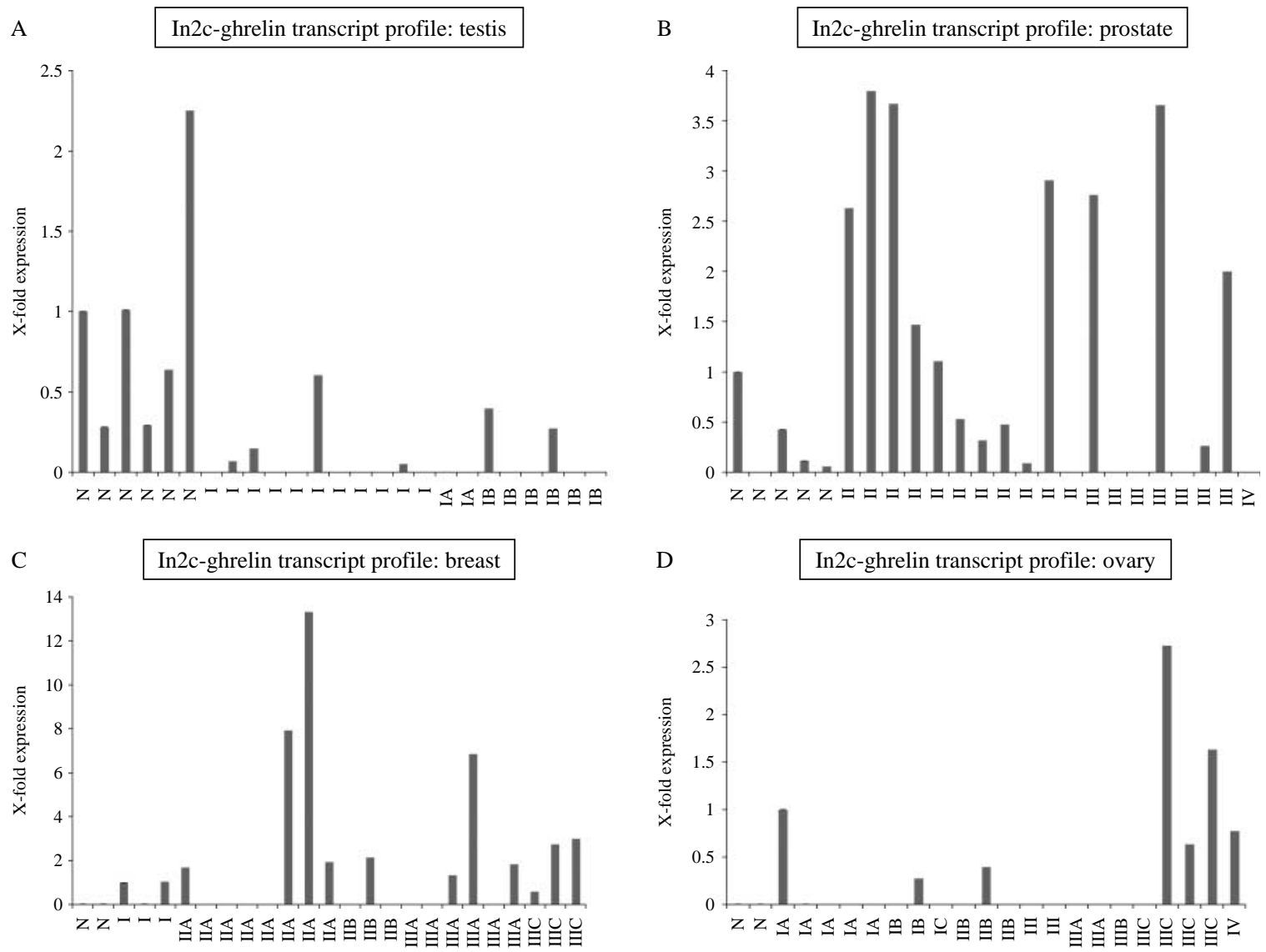

D

In2c-ghrelin transcript profile: ovary

\section{Figure 6}

Relative expression of in2c-ghrelin in cancer determined using real-time quantitative RT-PCR. The labels in $X$-axis indicate the clinical status of the subjects ( $\mathrm{N}$ denotes normal, Roman numerals indicate disease stages). Data

been observed for the LNCaP and DU145 cell lines (Cassoni et al. 2004, Yeh et al. 2005). We propose that the observed discrepancies may arise from the use of different forms of the cell lines, the different types of assays used and the handling and stability of the acylated ghrelin peptide.

In2c-ghrelin is expressed in all normal testis samples examined, while it is expressed in a small number of testicular tumours. This correlates well with previous studies, which have shown that the ghrelin peptide is present in normal human testis (Gaytan et al. 2004, Ishikawa et al. 2007) and in a subset of testicular tumours (Gaytan et al. 2004). Employing a small number of normal samples, we also demonstrate that in2c-ghrelin is expressed in breast and ovarian tumours but not in normal breast or ovary. The SKOV-3 ovarian cancer cell line expresses the in2c-ghrelin variant, but no expression was detected in the

represented as fold changes relative to the expression in a normal tissue sample (set at 1.0) or in the absence of expression in a normal tissue a tumour sample. (A) Testis, (B) prostate, (C) breast and (D) ovary.

hOSE17.1 normal ovary-derived cell line. Ghrelin has previously been shown to be expressed in breast cancer and, as is the case for prostate cancer, studies from other laboratories report different responses in cell proliferation assays when cell lines are treated with exogenous ghrelin peptide (Cassoni et al. 2001, Jeffery et al. 2005).

The in2c-ghrelin isoform is expressed in a limited number of normal tissues (including the testis) and at higher levels in many tumours. In normal tissues, in2c-ghrelin expression was most abundantly expressed in lymph node tissue. Interestingly, the LNCaP cell line, which demonstrated very high levels of in2c-ghrelin, is derived from a lymph node metastasis (Yu et al. 2009). Furthermore, in2c-ghrelin is expressed in peripheral blood leucocytes, indicating that it may play a role in immune regulation. Indeed, the ghrelin peptide has been shown to play an immunoregulatory role (Baatar et al. 2011). 
A
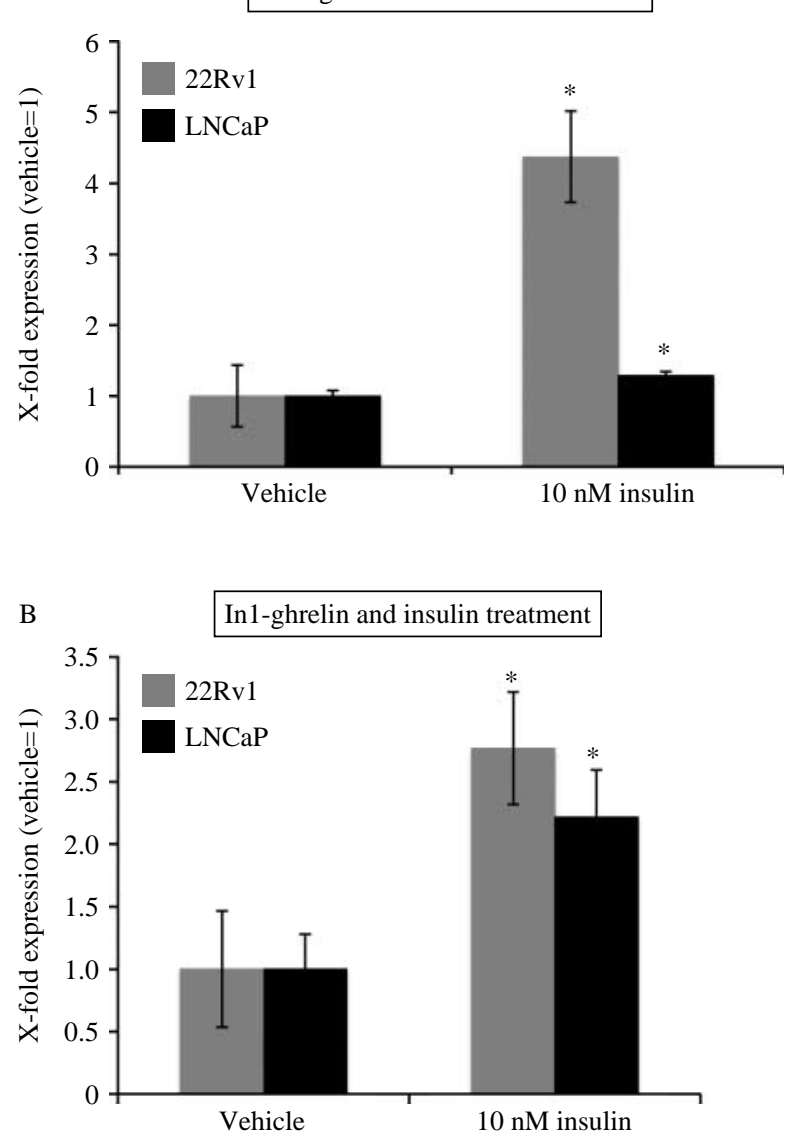

Figure 7

Real-time quantitative RT-PCR analysis of (A) in2-ghrelin and (B) in1-ghrelin gene expression in 22Rv1 and LNCaP prostate cancer cell lines in response to treatment with $10 \mathrm{nM}$ insulin over $48 \mathrm{~h}$. The housekeeping gene, ribosomal protein L32, was used as a reference for normalisation. Data are represented as means and S.E.M. with three technical replicates of three independent replicate experiments $(n=3) . * P<0.05$, significantly different from the vehicle-treated control (set at onefold) using Student's $t$-test.

A number of other ghrelin isoforms have also been described previously (Seim et al. 2009, 2011a), including exon 3-deleted preproghrelin (Jeffery et al. 2005, Yeh et al. 2005) and the intron 1-retained transcript (originally termed in2-ghrelin but renamed in1-ghrelin using the current ghrelin gene nomenclature; Kineman et al. 2007, Gahete et al. 2010, 2011). In1-ghrelin would encode a 117 amino acid polypeptide that includes the signal peptide of preproghrelin, the first 12 amino acids of the 28 amino acid ghrelin peptide sequence and a novel 81 amino acid C-terminal peptide, but not obestatin (Gahete et al. 2011). In1-ghrelin is regulated in response to metabolic stress in mice (Kineman et al. 2007) and is down-regulated in particular brain regions in Alzheimer's disease in humans (Gahete et al. 2010) and upregulated in breast cancer (Gahete et al. 2011).

We speculate that the in2c-ghrelin variant is another example that illustrates an emerging theme where mRNA transcripts encode ghrelin but not obestatin, as is the case for exon 3-deleted ghrelin and in1-ghrelin. Indeed, evidence is emerging that obestatin, the peptide derived from exon 3 of preproghrelin, may be a growth factor that could promote or inhibit cancer progression, depending on the cancer type (Pazos et al. 2007, 2009, Volante et al . 2009). Similarly, putative obestatin-coding transcripts that lack the ghrelin coding region are also expressed in prostate cancer cell lines (Seim et al. 2007). These studies suggest that cells can regulate the production of ghrelin gene-derived peptides independently by means of alternative splicing and this could partly explain the observed lack of correlation between plasma ghrelin and obestatin (or C-ghrelin) peptide levels (Bang et al. 2007, Pemberton et al. 2003). One small study has reported that the ratio of acylated ghrelin to total ghrelin (acyl and desacyl ghrelin combined) in the circulation was higher in prostate cancer patients compared with subjects with benign prostatic hyperplasia (Malendowicz et al. 2009). By contrast, obestatin was not elevated in these patients (Malendowicz et al. 2009).

Insulin regulates a large number of genes $\left(\mathrm{O}^{\prime}\right.$ Brien \& Granner 1996, Rome et al. 2003, Hartmann et al. 2009), and in this study, we have demonstrated that insulin increases the expression of in2c-ghrelin and in1-ghrelin in the LNCaP and 22Rv1 prostate cancer cell lines. Insulin treatment also up-regulates ghrelin expression in mouse stomach oxyntic glands (which are the major site of ghrelin expression; Toshinai et al. 2001) and in adipocytes (Gurriaran-Rodriguez et al. 2011). Conversely, insulin down-regulates the expression of wild-type and in1ghrelin mRNA in the mouse hypothalamus, where it has an effect on appetite regulation (Kineman et al. 2007, Fick et al. 2009). The regulation of ghrelin in cancer has yet to be established, and this is the first study to demonstrate regulation of ghrelin transcripts by insulin in cancer.

Although in2c-ghrelin is insulin regulated in the prostate, we failed to detect the in2c-ghrelin isoform in the pancreas itself, despite the fact that the wild-type ghrelin transcript and the ghrelin peptide are abundantly expressed in the endocrine pancreas and ghrelin appears to play an important role in glucose homoeostasis and insulin regulation (Granata et al. 2010). The importance of the ghrelin axis in the regulation of blood glucose was recently illustrated in a study of the ghrelin acylation

Published by Bioscientifica Ltd. 
enzyme, GOAT, knockout mouse, which is unable to produce acylated ghrelin. Under severe caloric restriction (60\%), GOAT knockout mice are unable to maintain glucose homoeostasis and die; however, animals can be rescued with the administration of acylated ghrelin or GH (Zhao et al. 2010). This finding has been contradicted, however, by a comprehensive study using a range of mouse models, suggesting that the ghrelin axis may not play an important role in insulin regulation in response to caloric restriction (Yi et al. 2012).

Ghrelin has been linked directly with obesity given its clear role in appetite, energy balance and metabolic regulation, and ghrelin and GOAT are important targets for the treatment of obesity (Lim et al. 2011). In addition to being a risk factor for cancer, obesity is associated with metabolic syndrome, which is also typified by hyperinsulinaemia (Hammarsten \& Peeker 2011). There is mounting evidence that elevated circulating insulin levels are positively associated with increased cancer risk and particularly with breast and prostate cancer (Amling 2005, Hammarsten \& Hogstedt 2005, Buschemeyer \& Freedland 2007, Ma et al. 2008, Gunter et al. 2009, Hammarsten et al. 2010, Healy et al. 2010, LeRoith 2010, Bao et al. 2011, Hammarsten \& Peeker 2011, Suissa et al. 2011, Wilson 2011). Although there have been few studies at the cellular level, insulin appears to play a role in the progression of prostate cancer. Insulin stimulates cell proliferation in cultured breast and prostate cancer cell lines (Lann \& LeRoith 2008, Pollak 2008) and promotes tumour progression by stimulating de novo steroidogenesis in prostate cancer (Lubik et al. 2011). Interestingly, diet-induced hyperinsulinaemia results in increased cell proliferation of LNCaP prostate cancer cell xenografts in mice (Venkateswaran et al. 2007). We show that in2c-ghrelin is expressed in the PC3 prostate cancer cell line, which is derived from a bone metastasis (Yu et al. 2009). Men with hyperinsulinaemia are more likely to develop bone metastases and progress faster to terminal, castrateresistant prostate cancer (Lubik et al. 2011). While hyperinsulinaemia has been associated with prostate cancer progression, androgen deprivation therapy, the standard treatment for advanced prostate cancer, frequently gives rise to metabolic syndrome and insulin resistance, with hyperinsulinaemia, elevated fasting blood glucose and elevated C-reactive peptide (Aggarwal et al. 2011). As insulin treatment leads to increased ghrelin expression in the LNCaP prostate cancer cell line, this may also increase cell proliferation in prostate cancer.

In conclusion, in this study, we have identified bona fide exons within intron 2 of the ghrelin gene locus
(GHRL) and described a novel ghrelin isoform that, together with the recently described in1-ghrelin isoform, is upregulated by insulin in prostate cancer cell lines. In2cghrelin includes cryptic exon sequence and would result in the translation of an 83 amino acid preproghrelin isoform that encodes ghrelin but not obestatin. In2cghrelin is expressed in a range of tumour samples derived from the prostate, breast and ovary, but in a limited number of normal tissues, including lymph nodes, stomach and testis. Further studies are warranted to elucidate the role of ghrelin gene products in normal physiology and in conditions associated with hyperinsulinaemia and in cancer.

\section{Supplementary data}

This is linked to the online version of the paper at http://dx.doi.org/10.1530/ JME-12-0150.

\section{Declaration of interest}

The authors declare that there is no conflict of interest that could be perceived as prejudicing the impartiality of the research reported.

\section{Funding}

This work was supported by grants from National Health and Medical Research Council (NHMRC; to A C H and L K C), the Cancer Council Queensland (to A C H and L K C), the Queensland University of Technology, the QUT ECARD (the Queensland University of Technology Early Career Academic Development) program (to E J W) and the Australian Prostate Cancer Research Centre, Queensland.

\section{Acknowledgements}

The authors would like to thank Dr Olivia Tan, IHBI, QUT, for supplying the hOSE17.1 ovarian cell line.

\section{References}

Aggarwal RR, Ryan CJ \& Chan JM 2013 Insulin-like growth factor pathway: a link between androgen deprivation therapy (ADT), insulin resistance, and disease progression in patients with prostate cancer? Urologic Oncology. In press. (doi:10.1016/j.urolonc.2011.05.001)

Amling CL 2005 Relationship between obesity and prostate cancer. Current Opinion in Urology 15 167-171. (doi:10.1097/01.mou.0000165550. 94663.fb)

Baatar D, Patel K \& Taub DD 2011 The effects of ghrelin on inflammation and the immune system. Molecular and Cellular Endocrinology 340 44-58. (doi:10.1016/j.mce.2011.04.019)

Bang AS, Soule SG, Yandle TG, Richards AM \& Pemberton CJ 2007 Characterisation of proghrelin peptides in mammalian tissue and plasma. Journal of Endocrinology 192 313-323. (doi:10.1677/JOE06-0021)

Bao Y, Nimptsch K, Wolpin BM, Michaud DS, Brand-Miller JC, Willett WC, Giovannucci E \& Fuchs CS 2011 Dietary insulin load, dietary insulin

Published by Bioscientifica Ltd. http://jme.endocrinology-journals.org DOI: 10.1530/JME-12-0150
C) 2013 Society for Endocrinology Printed in Great Britain 
index, and risk of pancreatic cancer. American Journal of Clinical Nutrition 94 862-868. (doi:10.3945/ajcn.110.011205)

Beaumont NJ, Skinner VO, Tan TM, Ramesh BS, Byrne DJ, MacColl GS Keen JN, Bouloux PM, Mikhailidis DP, Bruckdorfer KR et al. 2003 Ghrelin can bind to a species of high density lipoprotein associated with paraoxonase. Journal of Biological Chemistry 278 8877-8880. (doi:10.1074/jbc.C200575200)

Burset M, Seledtsov IA \& Solovyev VV 2000 Analysis of canonical and noncanonical splice sites in mammalian genomes. Nucleic Acids Research 28 4364-4375. (doi:10.1093/nar/28.21.4364)

Buschemeyer WC III \& Freedland SJ 2007 Obesity and prostate cancer: epidemiology and clinical implications. European Urology 52 331-343. (doi:10.1016/j.eururo.2007.04.069)

Cassoni P, Papotti M, Ghe C, Catapano F, Sapino A, Graziani A, Deghenghi R, Reissmann T, Ghigo E \& Muccioli G 2001 Identification, characterization, and biological activity of specific receptors for natural (ghrelin) and synthetic growth hormone secretagogues and analogs in human breast carcinomas and cell lines. Journal of Clinical Endocrinology and Metabolism 86 1738-1745. (doi:10.1210/jc.86.4.1738)

Cassoni P, Ghe C, Marrocco T, Tarabra E, Allia E, Catapano F, Deghenghi R, Ghigo E, Papotti M \& Muccioli G 2004 Expression of ghrelin and biological activity of specific receptors for ghrelin and des-acyl ghrelin in human prostate neoplasms and related cell lines. European Journal of Endocrinology 150 173-184. (doi:10.1530/eje.0.1500173)

Chopin L, Walpole C, Seim I, Cunningham P, Murray R, Whiteside E, Josh P \& Herington A 2011 Ghrelin and cancer. Molecular and Cellular Endocrinology 340 65-69. (doi:10.1016/j.mce.2011.04.013)

Chopin LK, Seim I, Walpole CM \& Herington AC 2012 The ghrelin axis-does it have an appetite for cancer progression? Endocrine Reviews 33 849-891. (doi:10.1210/er.2011-1007)

Clark TA, Schweitzer AC, Chen TX, Staples MK, Lu G, Wang H, Williams A \& Blume JE 2007 Discovery of tissue-specific exons using comprehensive human exon microarrays. Genome Biology 8 R64. (doi:10.1186/gb2007-8-4-r64)

Date Y, Kojima M, Hosada H, Sawaguchi A, Mondal M, Suganama T, Matsukura S, Kangawa K \& Nakazato M 2000 Ghrelin, a novel growth hormone releasing acylated peptide is synthesised in a distinct endocrine cell type in gastrointestinal tracts of rats and humans. Endocrinology 141 4255-4261. (doi:10.1210/en.141.11.4255)

Deboer MD 2011 Ghrelin and cachexia: will treatment with GHSR-1a agonists make a difference for patients suffering from chronic wasting syndromes? Molecular and Cellular Endocrinology 340 97-105. (doi:10.1016/j.mce.2011.02.012)

De Vriese C, Gregoire F, Lema-Kisoka R, Waelbroeck M, Robberecht P \& Delporte C 2004 Ghrelin degradation by serum and tissue homogenates: identification of the cleavage sites. Endocrinology 145 4997-5005. (doi:10.1210/en.2004-0569)

Diaz-Lezama N, Hernandez-Elvira M, Sandoval A, Monroy A, Felix R \& Monjaraz E 2010 Ghrelin inhibits proliferation and increases T-type $\mathrm{Ca} 2+$ channel expression in PC-3 human prostate carcinoma cells. Biochemical and Biophysical Research Communications 403 24-29. (doi:10.1016/j.bbrc.2010.10.100)

Eubanks LM, Stowe GN, De Lamo MarinS, Mayorov AV, Hixon MS \& Janda KD 2011 Identification of $\alpha 2$ macroglobulin as a major serum ghrelin esterase. Angewandte Chemie (International ed.) 50 10699-10702. (doi:10.1002/anie.201104512)

Fick LJ, Cai F \& Belsham DD 2009 Hypothalamic preproghrelin gene expression is repressed by insulin via both PI3-K/Akt and ERK1/2 MAPK pathways in immortalized, hypothalamic neurons. Neuroendocrinology 89 267-275. (doi:10.1159/000167698)

French PJ, Peeters J, Horsman S, Duijm E, Siccama I, van den Bent MJ, Luider TM, Kros JM, van der Spek P \& Sillevis Smitt PA 2007 Identification of differentially regulated splice variants and novel exons in glial brain tumors using exon expression arrays. Cancer Research 67 5635-5642. (doi:10.1158/0008-5472.CAN-06-2869)
Fujita PA, Rhead B, Zweig AS, Hinrichs AS, KarolchikD, Cline MS, Goldman M, Barber GP, Clawson H, Coelho A et al. 2011 The UCSC Genome Browser database: update 2011. Nucleic Acids Research 39 D876-D882. (doi:10.1093/nar/gkq963)

Gahete MD, Rubio A, Cordoba-Chacon J, Gracia-Navarro F, Kineman RD, Avila J, Luque RM \& Castano JP 2010 Expression of the ghrelin and neurotensin systems is altered in the temporal lobe of Alzheimer's disease patients. Journal of Alzheimer's Disease 22 819-828. (doi:10.3233/JAD-2010-100873)

Gahete MD, Cordoba-Chacon J, Hergueta-Redondo M, Martínez-Fuentes AJ, Kineman RD, Moreno-Bueno G, Luque RM \& Castano JP 2011 A novel human ghrelin variant (in1-ghrelin) and ghrelin-O-acyltransferase are overexpressed in breast cancer: potential pathophysiological relevance. PLOS ONE 6 e23302. (doi:10.1371/journal.pone.0023302)

Gaytan F, Barreiro ML, Caminos JE, Chopin LK, Herington AC, Morales C, Pinilla L, Paniagua R, Nistal M, Casanueva FF et al. 2004 Expression of ghrelin and its functional receptor, the type 1a growth hormone secretagogue receptor, in normal human testis and testicular tumors. Journal of Clinical Endocrinology and Metabolism 89 400-409. (doi:10.1210/jc.2003-031375)

Gnanapavan S, Kola B, Bustin S, Morris D, McGee P, Fairclough P, Bhattacharya S, Carpenter R, Grossman A \& Korbonits M 2002 The tissue distribution of the mRNA of ghrelin and subtypes of its receptor, GHS-R, in humans. Journal of Clinical Endocrinology and Metabolism $\mathbf{8 7}$ 2988. (doi:10.1210/jc.87.6.2988)

Granata R, Baragli A, Settanni F, Scarlatti F \& Ghigo E 2010 Unraveling the role of the ghrelin gene peptides in the endocrine pancreas. Journal of Molecular Endocrinology 45 107-118. (doi:10.1677/JME-10-0019)

Gunter MJ, Hoover DR, Yu H, Wassertheil-Smoller S, Rohan TE, Manson JE, Li J, Ho GY, Xue X, Anderson GL et al. 2009 Insulin, insulin-like growth factor-I, and risk of breast cancer in postmenopausal women. Journal of the National Cancer Institute 101 48-60. (doi:10.1093/jnci/djn415)

Gurriaran-Rodriguez U, Al-Massadi O, Crujeiras AB, Mosteiro CS, Amil-Diz M, Beiroa D, Nogueiras R, Seoane LM, Gallego R, Pazos Y et al. 2011 Preproghrelin expression is a key target for insulin action on adipogenesis. Journal of Endocrinology 210 R1-R7. (doi:10.1530/JOE11-0233)

Gutierrez JA, Solenberg PJ, Perkins DR, Willency JA, Knierman MD, Jin Z, Witcher DR, Luo S, Onyia JE \& Hale JE 2008 Ghrelin octanoylation mediated by an orphan lipid transferase. PNAS 105 6320-6325 (doi:10.1073/pnas.0800708105)

Hammarsten J \& Hogstedt B 2005 Hyperinsulinaemia: a prospective risk factor for lethal clinical prostate cancer. European Journal of Cancer $\mathbf{4 1}$ 2887-2895. (doi:10.1016/j.ejca.2005.09.003)

Hammarsten J \& Peeker R 2011 Urological aspects of the metabolic syndrome. Nature Reviews. Urology 8 483-494. (doi:10.1038/nrurol. 2011.112)

Hammarsten J, Damber JE, Peeker R, Mellstrom D \& Hogstedt B 2010 A higher prediagnostic insulin level is a prospective risk factor for incident prostate cancer. Cancer Epidemiology 34 574-579. (doi:10.1016/j.canep.2010.06.014)

Hartmann B, Castelo R, Blanchette M, Boue S, Rio DC \& Valcarcel J 2009 Global analysis of alternative splicing regulation by insulin and wingless signaling in Drosophila cells. Genome Biology 10 R11. (doi:10.1186/gb-2009-10-1-r11)

He C, Zhou F, Zuo Z, Cheng H \& Zhou R 2009 A global view of cancerspecific transcript variants by subtractive transcriptome-wide analysis. PLoS ONE 4 e4732. (doi:10.1371/journal.pone.0004732)

Healy LA, Ryan AM, Carroll P, Ennis D, Crowley V, Boyle T, Kennedy MJ, Connolly E \& Reynolds JV 2010 Metabolic syndrome, central obesity and insulin resistance are associated with adverse pathological features in postmenopausal breast cancer. Clinical Oncology 22 281-288. (doi:10.1016/j.clon.2010.02.001)

Holmes E, Davies I, Lowe G \& Ranganath LR 2009 Circulating ghrelin exists in both lipoprotein bound and free forms. Annals of Clinical Biochemistry 46 514-516. (doi:10.1258/acb.2009.008254) 
Hosoda H, Doi K, Nagaya N, Okumura H, Nakagawa E, Enomoto M, Ono F \& Kangawa K 2004 Optimum collection and storage conditions for ghrelin measurements: octanoyl modification of ghrelin is rapidly hydrolyzed to desacyl ghrelin in blood samples. Clinical Chemistry $\mathbf{5 0}$ 1077-1080. (doi:10.1373/clinchem.2003.025841)

Howard AD, Feighner SD, Cully DF, Arena JP, Liberator PA, Rosenblum CI, Hamelin M, Hreniuk DL, Palyha OC, Anderson J et al. 1996 A receptor in pituitary and hypothalamus that functions in growth hormone release. Science 273 974-977. (doi:10.1126/science.273.5277.974)

Isgaard J \& Granata R 2011 Ghrelin in cardiovascular disease and atherogenesis. Molecular and Cellular Endocrinology 340 59-64. (doi:10.1016/j.mce.2011.03.006)

Ishikawa T, Fujioka H, Ishimura T, Takenaka A \& Fujisawa M 2007 Ghrelin expression in human testis and serum testosterone level. Journal of Andrology 28 320-324. (doi:10.2164/jandrol.106.000810)

Jeffery PL, Herington AC \& Chopin LK 2002 Expression and action of the growth hormone releasing peptide ghrelin and its receptor in prostate cancer cell lines. Journal of Endocrinology 172 R7-R11. (doi:10.1677/ joe.0.172R007)

Jeffery P, Murray R, Yeh A, McNamara J, Duncan RP, Francis G, Herington A \& Chopin L 2005 Expression and function of the ghrelin axis, including a novel preproghrelin isoform, in human breast cancer tissues and cell lines. Endocrine-Related Cancer 12 839-850. (doi:10.1677/erc.1.00984)

Jeffery P, McDonald V, Tippett E \& McGuckin M 2011 Ghrelin in gastrointestinal disease. Molecular and Cellular Endocrinology 340 35-43. (doi:10.1016/j.mce.2011.03.002)

Johnson M, Zaretskaya I, Raytselis Y, Merezhuk Y, McGinnis S \& Madden TL 2008 NCBI BLAST: a better web interface. Nucleic Acids Research 36 W5-W9. (doi:10.1093/nar/gkn201)

Kineman RD, Gahete MD \& Luque RM 2007 Identification of a mouse ghrelin gene transcript that contains intron 2 and is regulated in the pituitary and hypothalamus in response to metabolic stress. Journal of Molecular Endocrinology 38 511-521. (doi:10.1677/JME-06-0026)

Kirchner H, Tong J, Tschop MH \& Pfluger PT 2010 Ghrelin and PYY in the regulation of energy balance and metabolism: lessons from mouse mutants. American Journal of Physiology. Endocrinology and Metabolism 298 E909-E919. (doi:10.1152/ajpendo.00191.2009)

Kojima M, Hosoda H, Date Y, Nakazato M, Matsuo H \& Kangawa K 1999 Ghrelin is a growth-hormone-releasing acylated peptide from stomach. Nature 402 656-660. (doi:10.1038/45230)

Lann D \& LeRoith D 2008 The role of endocrine insulin-like growth factor-I and insulin in breast cancer. Journal of Mammary Gland Biology and Neoplasia 13 371-379. (doi:10.1007/s10911-008-9100-x)

LeRoith D 2010 Can endogenous hyperinsulinaemia explain the increased risk of cancer development and mortality in type 2 diabetes: evidence from mouse models. Diabetes/Metabolism Research and Reviews 26 599-601. (doi:10.1002/dmrr.1139)

Lim CT, Kola B \& Korbonits M 2011 The ghrelin/GOAT/GHS-R system and energy metabolism. Reviews in Endocrine \& Metabolic Disorders 12 173-186. (doi:10.1007/s11154-011-9169-1)

Livak KJ \& Schmittgen TD 2001 Analysis of relative gene expression data using real-time quantitative PCR and the $2(-\Delta \Delta C(\mathrm{~T}))$ method. Methods 25 402-408. (doi:10.1006/meth.2001.1262)

Lu C, McFarland MS, Nesbitt RL, Williams AK, Chan S, Gomez-Lemus J, Autran AM, Al-Zahrani A, Chin JL, Izawa JI et al. 2012 Ghrelin receptor as a novel imaging target for prostatic neoplasms. Prostate 72 825-833. (doi:10.1002/pros.21484)

Lubik AA, Gunter JH, Hendy SC, Locke JA, Adomat HH, Thompson V, Herington A, Gleave ME, Pollak M \& Nelson CC 2011 Insulin increases de novo steroidogenesis in prostate cancer cells. Cancer Research $\mathbf{7 1}$ 5754-5764. (doi:10.1158/0008-5472.CAN-10-2470)

Ma J, Li H, Giovannucci E, Mucci L, Qiu W, Nguyen PL, Gaziano JM, Pollak M \& Stampfer MJ 2008 Prediagnostic body-mass index, plasma C-peptide concentration, and prostate cancer-specific mortality in men with prostate cancer: a long-term survival analysis. Lancet Oncology 9 1039-1047. (doi:10.1016/S1470-2045(08)70235-3)
Malendowicz W, Ziolkowska A, Szyszka M \& Kwias Z 2009 Elevated blood active ghrelin and unaltered total ghrelin and obestatin concentrations in prostate carcinoma. Urologia Internationalis 83 471-475. (doi:10.1159/000251190)

Menghi F, Jacques TS, Barenco M, Schwalbe EC, Clifford SC, Hubank M \& Ham J 2011 Genome-wide analysis of alternative splicing in medulloblastoma identifies splicing patterns characteristic of normal cerebellar development. Cancer Research 71 2045-2055. (doi:10.1158/0008-5472. CAN-10-2519)

Nakazato M, Murakami N, Date Y, Kojima M, Matsuo H, Kangawa K \& Matsukura S 2001 A role for ghrelin in the central regulation of feeding. Nature 409 194-198. (doi:10.1038/35051587)

Nilsen TW \& Graveley BR 2010 Expansion of the eukaryotic proteome by alternative splicing. Nature 463 457-463. (doi:10.1038/nature08909)

O’Brien RM \& Granner DK 1996 Regulation of gene expression by insulin. Physiological Reviews 76 1109-1161.

Patterson M, Murphy KG, le Roux CW, Ghatei MA \& Bloom SR 2005 Characterization of ghrelin-like immunoreactivity in human plasma. Journal of Clinical Endocrinology and Metabolism 90 2205-2211. (doi:10.1210/jc.2004-1641)

Pazos Y, Alvarez CJ, Camina JP \& Casanueva FF 2007 Stimulation of extracellular signal-regulated kinases and proliferation in the human gastric cancer cells KATO-III by obestatin. Growth Factors 25 373-381. (doi:10.1080/08977190801889313)

Pazos Y, Alvarez CJ, Camina JP, Al-Massadi O, Seoane LM \& Casanueva FF 2009 Role of obestatin on growth hormone secretion: an in vitro approach. Biochemical and Biophysical Research Communications 390 1377-1381. (doi:10.1016/j.bbrc.2009.10.163)

Pemberton C, Wimalasena P, Yandle T, Soule S \& Richards M 2003 $\mathrm{C}$-terminal pro-ghrelin peptides are present in the human circulation. Biochemical and Biophysical Research Communications 310 567-573. (doi:10.1016/j.bbrc.2003.09.045)

Pollak M 2008 Targeting insulin and insulin-like growth factor signalling in oncology. Current Opinion in Pharmacology 8 384-392. (doi:10.1016/j. coph.2008.07.004)

Rahman FA, Aziz N \& Coverley D 2010 Differential detection of alternatively spliced variants of Ciz1 in normal and cancer cells using a custom exon-junction microarray. BMC Cancer 10 482. (doi:10.1186/ 1471-2407-10-482)

Repaci A, Gambineri A, Pagotto U \& Pasquali R 2011 Ghrelin and reproductive disorders. Molecular and Cellular Endocrinology 340 70-79. (doi:10.1016/j.mce.2011.02.022)

Rome S, Clement K, Rabasa-Lhoret R, Loizon E, Poitou C, Barsh GS, Riou JP, Laville M \& Vidal H 2003 Microarray profiling of human skeletal muscle reveals that insulin regulates approximately 800 genes during a hyperinsulinemic clamp. Journal of Biological Chemistry $\mathbf{2 7 8}$ 18063-18068. (doi:10.1074/jbc.M300293200)

Romero A, Kirchner H, Heppner K, Pfluger PT, Tschop MH \& Nogueiras R 2010 GOAT: the master switch for the ghrelin system? European Journal of Endocrinology 163 1-8. (doi:10.1530/EJE-10-0099)

Satou M, Nishi Y, Yoh J, Hattori Y \& Sugimoto H 2010 Identification and characterization of acyl-protein thioesterase $1 /$ lysophospholipase I as a ghrelin deacylation/lysophospholipid hydrolyzing enzyme in fetal bovine serum and conditioned medium. Endocrinology $1514765-4775$. (doi:10.1210/en.2010-0412)

Scerif M, Goldstone AP \& Korbonits M 2011 Ghrelin in obesity and endocrine diseases. Molecular and Cellular Endocrinology 340 15-25. (doi:10.1016/j.mce.2011.02.011)

Seim I, Collet C, Herington AC \& Chopin LK 2007 Revised genomic structure of the human ghrelin gene and identification of novel exons, alternative splice variants and natural antisense transcripts. $B M C$ Genomics 8 298. (doi:10.1186/1471-2164-8-298)

Seim I, Herington AC \& Chopin LK 2009 New insights into the molecular complexity of the ghrelin gene locus. Cytokine \& Growth Factor Reviews 20 297-304. (doi:10.1016/j.cytogfr.2009.07.006) http://jme.endocrinology-journals.org DOI: 10.1530/JME-12-0150
() 2013 Society for Endocrinology Printed in Great Britain 
Seim I, Josh P, Cunningham P, Herington A \& Chopin L 2011 a Ghrelin axis genes, peptides and receptors: recent findings and future challenges. Molecular and Cellular Endocrinology 340 3-9. (doi:10.1016/j.mce. 2011.05.002)

Seim I, Walpole C, Amorim L, Josh P, Herington A \& Chopin L $2011 b$ The expanding roles of the ghrelin-gene derived peptide obestatin in health and disease. Molecular and Cellular Endocrinology 340 111-117. (doi:10.1016/j.mce.2011.03.018)

Skotheim RI \& Nees M 2007 Alternative splicing in cancer: noise, functional, or systematic? International Journal of Biochemistry \& Cell Biology 39 1432-1449. (doi:10.1016/j.biocel.2007.02.016)

Smyth G 2005 Limma: linear models for microarray data. In Bioinformatics and Computational Biology Solutions using $R$ and Bioconductor, pp 397-420. Eds. R Gentleman, V Carey, S Dudoit, R Irizarry, W Huber. New York: Springer

Steiger A, Dresler M, Schussler P \& Kluge M 2011 Ghrelin in mental health, sleep, memory. Molecular and Cellular Endocrinology 340 88-96. (doi:10.1016/j.mce.2011.02.013)

Suissa S, Azoulay L, Dell'aniello S, Evans M, Vora J \& Pollak M 2011 Longterm effects of insulin glargine on the risk of breast cancer. Diabetologia 54 2254-2262. (doi:10.1007/s00125-011-2190-9)

Takahashi T, Ida T, Sato T, Nakashima Y, Nakamura Y, Tsuji A \& Kojima M 2009 Production of $n$-octanoyl-modified ghrelin in cultured cells requires prohormone processing protease and ghrelin $O$-acyltransferase, as well as $n$-octanoic acid. Journal of Biochemistry 146 675-682. (doi:10.1093/jb/mvp112)

Toshinai K, Mondal MS, Nakazato M, Date Y, Murakami N, Kojima M, Kangawa K \& Matsukura S 2001 Upregulation of ghrelin expression in the stomach upon fasting, insulin-induced hypoglycemia, and leptin administration. Biochemical and Biophysical Research Communications 281 1220-1225. (doi:10.1006/bbrc.2001.4518)

Ueberberg B, Unger N, Saeger W, Mann K \& Petersenn S 2009 Expression of ghrelin and its receptor in human tissues. Hormone and Metabolic Research 41 814-821. (doi:10.1055/s-0029-1233462)

Ukkola O 2011 Ghrelin in type 2 diabetes mellitus and metabolic syndrome. Molecular and Cellular Endocrinology 340 26-28. (doi:10.1016/j.mce.2011.02.009)

Venkateswaran V, Haddad AQ, Fleshner NE, Fan R, Sugar LM, Nam R, Klotz LH \& Pollak M 2007 Association of diet-induced hyperinsulinemia with accelerated growth of prostate cancer (LNCaP) xenografts. Journal of the National Cancer Institute 99 1793-1800. (doi:10.1093/jnci/djm231)
Volante M, Rosas R, Ceppi P, Rapa I, Cassoni P, Wiedenmann B, Settanni F, Granata R \& Papotti M 2009 Obestatin in human neuroendocrine tissues and tumours: expression and effect on tumour growth. Journal of Pathology 218 458-466. (doi:10.1002/path.2551)

Wilson C 2011 Diabetes: long-term use of insulin glargine might increase the risk of breast cancer. Nature Reviews. Endocrinology 7499. (doi:10.1038/nrendo.2011.112)

Wren A, Small C, Ward H, Murphy K, Dakin C, Taheri S, Kennedy A, Roberts G, Morgan D, Ghatei M et al. 2000 The novel hypothalamic peptide ghrelin stimulates food intake and growth hormone secretion. Endocrinology 141 4325-4328. (doi:10.1210/en.141.11.4325)

Yang J, Brown MS, Liang G, Grishin NV \& Goldstein JL 2008 Identification of the acyltransferase that octanoylates ghrelin, an appetite-stimulating peptide hormone. Cell 132 387-396. (doi:10.1016/ j.cell.2008.01.017)

Yeh A, Jeffery PL, Duncan RP, Herington A \& Chopin L 2005 Ghrelin and a novel preproghrelin isoform are highly expressed in prostate cancer and ghrelin activates mitogen-activated protein kinase in prostate cancer. Clinical Cancer Research 11 8295-8303. (doi:10.1158/10780432.CCR-05-0443)

Yi CX, Heppner K \& Tschop MH 2011 Ghrelin in eating disorders. Molecular and Cellular Endocrinology 340 29-34. (doi:10.1016/ j.mce.2011.03.001)

Yi CX, Heppner KM, Kirchner H, Tong J, Bielohuby M, Gaylinn BD, Muller TD, Bartley E, Davis HW, Zhao Y et al. 2012 The GOAT-ghrelin system is not essential for hypoglycemia prevention during prolonged calorie restriction. PLOS ONE 7 e32100. (doi:10.1371/journal.pone. 0032100)

Yu SQ, Lai KP, Xia SJ, Chang HC, Chang C, Yeh S et al. 2009 The diverse and contrasting effects of using human prostate cancer cell lines to study androgen receptor roles in prostate cancer. Asian Journal of Andrology $\mathbf{1 1}$ 39-48. (doi:10.1038/aja.2008.44)

Zhang J, Ren P-G, Avsian-Kretchmer O, Luo C-W, Raucg R, Klein C \& Hsueh A 2005 Obestatin, a peptide encoded by the ghrelin gene, opposes ghrelin's effects on food intake. Science 310 996-999. (doi:10.1126/science. 1117255)

Zhao TJ, Liang G, Li RL, Xie X, Sleeman MW, Murphy AJ, Valenzuela DM, Yancopoulos GD, Goldstein JL \& Brown MS 2010 Ghrelin $O$-acyltransferase (GOAT) is essential for growth hormone-mediated survival of calorie-restricted mice. PNAS 107 7467-7472. (doi:10.1073/ pnas.1002271107)

Received in final form 3 December 2012

Accepted 24 December 2012

Accepted Preprint published online 24 December 2012
() 2013 Society for Endocrinology Printed in Great Britain
Published by Bioscientifica Ltd 